\title{
Antibiotic Resistance Profile of Gram Positive Bacteria Isolated from Wound Infections in Minna, Bida, Kontagora and Suleja Area of Niger State
}

\author{
Sani R. A. ${ }^{1}$, Garba S. A. ${ }^{2}$, Oyewole O. A. ${ }^{2, *}$, Ibrahim A. ${ }^{3}$ \\ ${ }^{1}$ Hospital Management Board, Minna, Niger State \\ ${ }^{2}$ Department of Microbiology, Federal University of Technology Minna, Niger State \\ ${ }^{3}$ College of Nursing Sciences, School of Midwifery, Minna, Niger State
}

\begin{abstract}
Antibiotics resistance profiles of gram positive bacteria isolated from wound infections in four (4) General Hospitals (Bida, Kontagora, Minna and Suleja) in Niger State was carried out. Organisms isolated from surgical wounds were Staphylococcus aureus and Streptococcus pyogenes. Five hundred (500) samples (i.e. Two hundred (200) samples in Minna, One hundred (100) samples each from Suleja, Kontagora and Bida) of wound exudates from surgical wounds sites were analysed for their resistance pattern. From the five hundred (500) samples collected from all the locations, one hundred and twenty one samples (121) had Strept. pyogenes, one hundred and ninety seven (197) samples had S. aureus. S. aureus was more frequently isolated (62\%) than Strept. pyogenes (38\%) from wounds in all the locations. Both bacteria were tested for sensitivity to Tarivid, Pefloxacin, Ciprofloxacin, Augmentin, Gentamycin, Streptomycin, Ceporex,

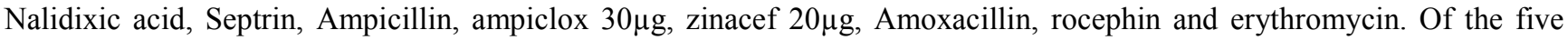
hundred (500) wound samples from various locations 318 (64\%) yielded growths while 182 samples (36\%) yielded no growths. Most of all the isolates were sensitive to ciprofloxacin, pefloxacin and Tarivid while others were resistant to remaining antibiotics. S. aureus showed a higher resistance profile to most antibiotics used than Strept. pyogenes.
\end{abstract}

Keywords Antibiotic, Resistance, Sensitive, Surgical Wounds, Gram Positive

\section{Introduction}

All surgical wounds are contaminated by both pathogens and body commensals ranging from bacteria and fungi to other parasites[1-4]. The common gram positive organisms are the $\beta$ - haemolytic streptococcus - Streptococcus pyogenes and Staphylococcus aureus. The gram negative aerobic rod is Pseudomonas aeruginosa. The facultative anaerobes include Enterobacter species, Escherichia coli, Klebsiella species and Proteus species. The fungi are Candida species and Aspergillus species[5,6], but the development of infection in the site depends on complex interplay of many factors[7]. These may be microbial virulence[1], patient risk factors like diabetes, cigarette smoking, obesity, and coincident remote site infections or colonization[8] and operation-related risk factors including prolonged hospital stay before surgery, duration of the operation, tissue trauma, poor homeostasis, and foreign materials in the wound.

The presence of foreign materials increases the risk of serious infection even with relatively small bacterial

* Corresponding author:

oyewolefemi@gmail.com (Oyewole, O.A.)

Published online at http://journal.sapub.org/health

Copyright (C) 2012 Scientific \& Academic Publishing. All Rights Reserved inoculums[9]. The widespread uses of antibiotics, together with the length of time over which they have been available have led to major problems of resistant organisms, contributing to morbidity and mortality $[4,10]$. Antimicrobial resistance can increase complications and costs associated with procedures and treatment. Antimicrobial resistance among pathogens of wound infections is on the increase. The control of wound infections has become more challenging due to widespread bacterial resistance to antibiotics and to a greater incidence of infections caused by methicillin-resistant $S$. aureus (MRSA) and polymicrobic flora $[4,10,11]$.

Knowledge of the causative agents of wound infection in a specific geographic region will therefore be useful in the selection of antimicrobials for empiric therapy. The objective of the present study is to determine the antibiotic resistance profile of gram positive bacteria isolated from surgical wounds in Minna, Bida, Kontagora and Suleja areas of Niger State.

\section{Materials and Methods}

\subsection{Collection of Samples}

Wounds samples were collected from five hundred (500) 
patients that undergo surgical operation in four (4) general hospitals in Minna, Bida, Kontagora and Suleja areas of Niger State. 200 samples were collected from general hospital in Minna while 100 samples were collected each from Bida, Kontagora and Suleja general hospitals. The wound types included boils, whitlow, abscesses, cervicitis, trauma wounds, burns, systemic ulcers, insect bites and swelling of no specific etiology. These samples were transferred to the Microbiology laboratory of Federal University of Technology, Minna for further analysis.

\subsection{Characterization and Identification of the Isolates}

The collected samples were streaked on freshly prepared nutrient agar plates and incubated aerobically and anaerobically at $37^{\circ} \mathrm{C}$ for 24 hours. Bacterial colonies differing in size, shape and colour were selected from the different plates and further subcultured on nutrient agar by the streak plate technique and incubated at $37^{\circ} \mathrm{C}$ for 24 hours after which, were maintained on agar slants for further characterization and identification. The bacterial isolates were characterized based on colonial and cell morphology, growth on differential/selective media and biochemical tests which include Gram's reaction, indole tests, methyl red, Voges-Proskauer, Citrate Utilization, Motility, endospore, utilization of carbohydrates such as glucose, sucrose, mannitol, lactose and fructose, oxidase, catalase, coagulase and starch hydrolysis test[12]. The bacterial isolates were identified by comparing their characteristics with those of known taxonomy using the schemes of[13].

\subsection{Susceptibility of Isolates to Various Antibiotics}

Antibiotic sensitivity test were carried out on all isolates using paper (New Man England) disc diffusion technique. A total of 10 antibiotics were tested and $0.2 \mathrm{ml}$ of $12 \mathrm{~h}$ peptone water culture of test organism was used to inoculate each organism on a dry sterile nutrient agar plate. The resistant profiles of bacteria isolated from surgical wounds were determined by standard methods. The antibiotic discs used are gram positive sensitive.

\section{Results}

\subsection{Microorganisms Isolated from Samples at Each Location}

Table 1 shows the gram positive bacteria isolated from wound samples in various general hospitals examined. $S$. aureus and Strept. pyogenes were the bacteria isolated. $S$. aureus had the higher occurrence in all four locations (62\%) while Strept. pyogenes had occurrence of $38 \%$.

\subsection{Antibiotic Resistance of Bacteria in Minna}

Antibiotics resistance of bacteria isolated in Minna General Hospital is presented in Table 2. S. aureus had a total resistance of 397 while Strept. pyogenes had 138. S. aureus had a total susceptibility of 483 while Strept. pyogenes had 322 in all the antibiotics examined.

\subsection{Antibiotic Resistance of Bacteria in Bida}

Antibiotics resistance of bacteria isolated in Bida General Hospital is presented in Table 3. S. aureus had a total resistance of 162 while Strept. pyogenes had 124. S. aureus had a total susceptibility of 238 while Strept. pyogenes had 166 in all the antibiotics examined.

\subsection{Antibiotic Resistance of Bacteria in Kontagora}

Antibiotics resistance of bacteria isolated in Kontagora General Hospital is presented in Table 4. S. aureus had a total resistance of 269 while Strept. pyogenes had 65. S. aureus had a total susceptibility of 231 while Strept. pyogenes had 205 in all the antibiotics examined.

\subsection{Antibiotic Resistance of Bacteria in Suleja}

Antibiotics resistance of bacteria isolated in Suleja General Hospital is presented in Table 4. S. aureus had a total resistance of 147 while Strept. pyogenes had 33. S. aureus had a total susceptibility of 43 while Strept. pyogenes had 157 in all the antibiotics examined.

Table 1. Microorganisms isolated from samples at each location

\begin{tabular}{|c|c|c|c|}
\hline Location & $\begin{array}{c}\text { Number of } \\
\text { Samples }\end{array}$ & S. aureus & Strept. pyogenes \\
\hline Minna & 200 & $88(65 \%)$ & $47(35 \%)$ \\
\hline Kontagora & 100 & $50(65 \%)$ & $27(35 \%)$ \\
\hline Suleja & 100 & $19(50 \%)$ & $19(50 \%)$ \\
\hline Bida & 100 & $40(59 \%)$ & $28(41 \%)$ \\
\hline Total & 500 & $197(62 \%)$ & $121(38 \%)$ \\
\hline
\end{tabular}

NB: Values in parenthesis are \% occurrence of isolate

\section{Discussion}

Staphylococcus aureus is the leading cause of wound infection both surgical and accidental followed by $S$. epidemidis and they are pyogenic, meaning that they characteristically cause purulent discharge, otherwise known as pus[14]. Treatment of staphylococcal infection has been problematic because of the development of resistance to different antimicrobial medications by production of either plasmid encoded beta-lactamase, modification of penicillin binding proteins[14]. S. aureus showed resistance to Erythromycin, Zinacef, Amoxacillin, Ampiclox and Septrin in all the locations except in Bida. The percentage resistant ranged from $60-68 \%[15]$. The ability of staphylococci to persist in adverse environments and their extraordinary potential to develop antimicrobial resistance may contribute to resistance patterns in sites of isolation and locations[16]. In the year 2000, a new method of reducing the problem of resistance was developed, that is using the combination of two substances that act synergistically. Despite the uses of synergistic antibiotics e.g. ampiclox, S. aureus was able to develop resistance to this drug in all the locations (Bida, Minna, Suleja and Kontagora). Also, the resistance pattern of S. aureus and S. epidermidis in Minna, Bida, Kontagora and Suleja is not in agreement with the study of[17]. 
Table 2. Antibiotics Resistance of Gram Positive Bacteria from Minna General Hospital

\begin{tabular}{|c|c|c|c|c|}
\hline \multirow{2}{*}{ Antibiotics } & \multicolumn{2}{|c|}{ S. aureus } & \multicolumn{2}{c|}{ Strept. pyogenes } \\
\cline { 2 - 5 } & $\mathrm{R}$ & $\mathrm{Su}$ & $\mathrm{R}$ & $\mathrm{Su}$ \\
\hline $\mathrm{PEF}$ & 13 & 75 & 3 & 44 \\
\hline $\mathrm{CN}$ & 39 & 49 & 11 & 36 \\
\hline $\mathrm{APX}$ & 54 & 34 & 27 & 20 \\
\hline $\mathrm{Z}$ & 60 & 28 & 30 & 17 \\
\hline AML & 60 & 28 & 24 & 23 \\
\hline $\mathrm{RO}$ & 31 & 57 & 4 & 43 \\
\hline $\mathrm{CPX}$ & 10 & 78 & 1 & 36 \\
\hline $\mathrm{S}$ & 20 & 68 & 7 & 40 \\
\hline SXT & 50 & 38 & 16 & 31 \\
\hline E & 60 & 28 & 15 & 32 \\
\hline TOTAL & 397 & 483 & 138 & 322 \\
\hline
\end{tabular}

Key: $\mathrm{PEF}=$ Pefloxacin, $\mathrm{CN}=$ Gentamycin, $\mathrm{APX}=$ Ampiclox, $\mathrm{Z}=$ Zinacef, $\mathrm{AML}=$ Amoxacillin, $\mathrm{RO}=$ Rocephin, $\mathrm{CPX}=$ Ciprofloxacin, $\mathrm{S}=$ Streptomycin, SXT $=$ Septrin, E = Erythromycin, $\mathrm{R}=$ Resistant, $\mathrm{Su}=$ Susceptible

Table 3. Antibiotics Resistance of Gram Positive Bacteria from Bida General Hospital

\begin{tabular}{|c|c|c|c|c|}
\hline \multirow{2}{*}{ Antibiotics } & \multicolumn{2}{|c|}{ S. aureus } & \multicolumn{2}{c|}{ Strept. pyogenes } \\
\cline { 2 - 5 } & $\mathrm{R}$ & $\mathrm{Su}$ & $\mathrm{R}$ & $\mathrm{Su}$ \\
\hline $\mathrm{PEF}$ & 9 & 31 & 4 & 24 \\
\hline $\mathrm{CN}$ & 11 & 29 & 11 & 17 \\
\hline $\mathrm{APX}$ & 22 & 18 & 17 & 21 \\
\hline $\mathrm{Z}$ & 25 & 15 & 20 & 8 \\
\hline $\mathrm{AML}$ & 21 & 19 & 18 & 10 \\
\hline $\mathrm{RO}$ & 12 & 28 & 10 & 18 \\
\hline $\mathrm{CPX}$ & 11 & 29 & 5 & 23 \\
\hline $\mathrm{S}$ & 15 & 25 & 7 & 21 \\
\hline SXT & 18 & 22 & 14 & 14 \\
\hline E & 18 & 22 & 18 & 10 \\
\hline TOTAL & 162 & 238 & 124 & 166 \\
\hline
\end{tabular}

Key: PEF $=$ Pefloxacin, $\mathrm{CN}=$ Gentamycin, $\mathrm{APX}=$ Ampiclox, $\mathrm{Z}=\mathrm{Zi}-$ nacef, $\mathrm{AML}=$ Amoxacillin, $\mathrm{Ro}=$ Rocephin, $\mathrm{CPX}=$ Ciprofloxacin $=$ Streptomycin, SXT = Septrin, E = Erythromycin, $\mathrm{R}=$ Resistant, $\mathrm{Su}=$ Susceptible

Table 4. Antibiotics Resistance of Gram Positive Bacteria from Kontagora General Hospital

\begin{tabular}{|c|c|c|c|c|}
\hline \multirow{2}{*}{ Antibiotics } & \multicolumn{2}{|c|}{ S. aureus } & \multicolumn{2}{c|}{ Strept. pyogenes } \\
\cline { 2 - 5 } & $\mathrm{R}$ & $\mathrm{Su}$ & $\mathrm{R}$ & $\mathrm{Su}$ \\
\hline PEF & 13 & 37 & 4 & 23 \\
\hline $\mathrm{CN}$ & 16 & 34 & 5 & 22 \\
\hline $\mathrm{APX}$ & 26 & 24 & 8 & 19 \\
\hline $\mathrm{Z}$ & 29 & 21 & 7 & 20 \\
\hline AML & 27 & 23 & 7 & 20 \\
\hline RO & 27 & 23 & 5 & 22 \\
\hline CPX & 28 & 22 & 6 & 21 \\
\hline S & 27 & 23 & 7 & 20 \\
\hline SXT & 36 & 14 & 9 & 18 \\
\hline E & 40 & 10 & 7 & 20 \\
\hline TOTAL & 269 & 231 & 65 & 205 \\
\hline
\end{tabular}

Key: $\mathrm{PEF}=$ Pefloxacin, $\mathrm{CN}=$ Gentamycin, $\mathrm{APX}=$ Ampiclox, $\mathrm{Z}=$ Zinacef, $\mathrm{AML}=$ Amoxacillin, $\mathrm{Ro}=$ Rocephin, $\mathrm{CPX}=$ Ciprofloxacin, $\mathrm{S}=$ Streptomycin, $\mathrm{SXT}=$ Septrin, $\mathrm{E}=$ Erythromycin, $\mathrm{R}=$ Resistant, $\mathrm{Su}=$ Susceptible
Table 5. Antibiotics Resistance of Gram Positive Bacteria from Suleja General Hospital

\begin{tabular}{|c|c|c|c|c|}
\hline \multirow{2}{*}{ Antibiotics } & \multicolumn{2}{|c|}{ S. aureus } & \multicolumn{2}{c|}{ Strept. pyogenes } \\
\cline { 2 - 5 } & $\mathrm{R}$ & $\mathrm{Su}$ & $\mathrm{R}$ & $\mathrm{Su}$ \\
\hline $\mathrm{PEF}$ & 13 & 6 & 2 & 17 \\
\hline $\mathrm{CN}$ & 11 & 8 & 0 & 19 \\
\hline $\mathrm{APX}$ & 11 & 8 & 4 & 15 \\
\hline $\mathrm{Z}$ & 13 & 6 & 5 & 14 \\
\hline $\mathrm{AML}$ & 16 & 3 & 6 & 13 \\
\hline $\mathrm{RO}$ & 15 & 4 & 7 & 12 \\
\hline $\mathrm{CPX}$ & 14 & 5 & 1 & 18 \\
\hline $\mathrm{S}$ & 18 & 1 & 1 & 18 \\
\hline SXT & 17 & 2 & 3 & 16 \\
\hline E & 19 & 0 & 4 & 15 \\
\hline TOTAL & 147 & 43 & 33 & 157 \\
\hline
\end{tabular}

Key: $\mathrm{PEF}=$ Pefloxacin, $\mathrm{CN}=$ Gentamycin, $\mathrm{APX}=$ Ampiclox, $\mathrm{Z}=\mathrm{Zi}-$ nacef, $\mathrm{AML}=$ Amoxacillin, $\mathrm{RO}=$ Rocephin, $\mathrm{CPX}=$ Ciprofloxacin, $\mathrm{S}=$ Streptomycin, $\mathrm{SXT}=$ Septrin, $\mathrm{E}=$ Erythromycin, $\mathrm{R}=$ Resistant, $\mathrm{Su}=$ Susceptible

The susceptibility of $S$. aureus to Ciprofloxacin, Streptomycin and Pefloxacin was generally high compared to other antibiotics. The susceptibility of $S$. aureus to pefloxacin may be due to its uncommon use or being a new medication[18].[18] reported that any latest or new drug use in clinics, take an average of 7 - 10years before microorganisms can be resistant to them. Susceptibility of $S$. aureus to Ciprofloxacin, Streptomycin and Pefloxacin may also be due to their mechanism of action. This suggests that the penicillinase-resistant anti-staphylococcal agents should be selected as a first choice when treating infections[19].

Recently, the frequency of isolation of MRSA from wound infections has been increasing[20]. The results of this study, however, were not compatible with the report of[20] regarding the susceptibility of $S$. aureus to some antimicrobial drugs, and this apparent conflict will need to be evaluated in more detail using many more clinically isolated strains. Among the antibiotics tested for S. epidermidis, ciprofloxation showed the highest rates of efficacy.

The resistance of Strept. pyogenes to Zinacef, Ampiclox and amoxicillin may be due to acquisition of resistant gene from other culture stains[14]. The resistance of this organism to these drugs in Minna and Bida was not in line with the findings of[21] but the susceptibility of these antibiotics in other locations (Suleja and Kontagora) to Strept. pyogenes was in agreement with[21]. The susceptibility of Strept. pyogenes to these drugs in Suleja and Kontagora may be due to synergetic effect of ampiclox. S. pyogenes is a very important bacterial pathogen in children and adults causing community-acquired diseases, such as upper respiratory tract infections (tonsillitis), skin infections, soft tissue infections and wounds infections which are among the most frequent reasons for seeking of medical advice[14]. The resistance of S. aureus and Strept. pyogenes to Erythromycin found in all the location was also similar to the findings of[22].

\section{Conclusions}

The findings of this study suggest that bacterial resistance 
in surgical wound infections is becoming serious menace in all the study area.

Staphylococcus aureus is still the most frequently involved pathogen, showing high resistance rates of bacteria isolated from surgical wounds.

Tarivid, ciprofloxacin and Pefloxacin are the best therapeutic options to treat these infections because of the less resistant caused by these organisms.

\section{REFERENCES}

[1] Bowler, C., Chigbu, O. C. and Giacometti, H. (2001). Emergence of Antimicrobial Resistance Bacteria. Journal of Antimicrobial and Chemotherapy 23:12 - 23 .

[2] Anguzu, J.R. and Olila, D. (2007). Drug sensitivity patterns of bacterial isolates from septic post-operative wounds in a regional referral hospital in Uganda. Afr. Health Sci., 7(3): 148-154.

[3] Adegoke, A. A., Tom, M., Okoh, A.I.1 and Jacob, S. (2010). Studies on multiple antibiotic resistant bacteria isolated from surgical site infection Scientific Research and Essays 5(24), pp. 3876-3881.

[4] Sani, R.A., Garba, S.A. and Oyewole, O.A. (2012). Antibiotic Resistance Profile of Gram Negative Bacteria Isolated from Surgical Wounds in Minna, Bida, Kontagora and Suleja Areas of Niger State. American Journal of Medicine and Medical Sciences 2 (1): 20-24.

[5] Gus Gunzalez Bronze MS, Drevets DA, Glatt A, Mylonakis E, Burke AC (2006). Surgical Wound Infection, available in http://www.emedicine.com/MED/topic1929.htm.

[6] Mordi, R. M. and Momoh, M. I. (2009). Incidence of Proteus species in Wound Infections and Their Sensitivity Pattern in the University of Benin Teaching Hospital. African Journal of Biotechnology 8(5):725 - 730.

[7] Olsen, M.A., Nepple, J.J. and Riew, K.D. (2008). Risk Factors for Surgical Site Infection Following Orthopaedic Spinal Operations. J. Bone Joint Surg. (American), 90: 62-69.

[8] Reichman, D.E. and Greenberg, J.A. (2009). Reducing Surgical Site Infections: A Review. Rev. Obstet. Gynecol., 2(4): 212-221.

[9] Rubin, R.H. (2006). Surgical wound infection: epidemiology, pathogenesis, diagnosis and management. BMC Infect. Dis., 6: 171-172.

[10] Mulugeta, K. A. and Bayeh, A. B. (2011). Bacteriology and antibiogram of pathogens from wound infections at Dessie
Laboratory, North East Ethiopia Tanzania Journal of Health Research 13 (4): 1-10.

[11] Akinjogunla, O. J., Adegoke, A. A., Mboto, C., Chukwudebelu, I. C. and Udokang, I. (2009) Bacteriology of automobile accident wounds infection. International Journal of Medicine and Medical Sciences 1: 23-27.

[12] Oyeleke, S. B. and Manga, B. S. (2008). Essentials of Laboratory Practical in Microbiology, 1st Edition. Tobest Publishers, Minna, Nigeria, pp. $28-62$.

[13] Cowan, S. T. and Steel, K. J. (1993). Manual for the Identification of Medical Bacteria. 2nd Edition. Cambridge University Press, London, pp. 205-209.

[14] Nester, E. W., Anderson, D. G., Roberts, C. E., Pearsall, N. N. and Nester, M. T. (2004). Microbiology: A Human Perspective 4th Edn, McGraw Hill, New York. Pp 509 - 528.

[15] Hoekstra, K. A. and Paulton, R.J.L. (2002). Clinical Prevalence and Antimicrobial Susceptibility of Staphylococcus aureus and Staph intermedius in Dogs. Journal of Applied Microbiology 93: 406-413.

[16] Normand, E.H., Gibson, N.R., Reid, S.W., Carmichael, S. and Taylor, D.J. (2000) Antimicrobial-Resistance Trends in Bacterial Isolates from Companion Animal Community Practice in the UK. Preventative Veterinary Medicine 46: 267-278.

[17] Bashir, A., Mujahid, T. Y. and Jehan, M. (2006). Antibiotic Resistance Profile: Isolation and Characterization of Clinical Isolates of Staphylococci from Patients with Community Acquired Skin Infections. Pakistan Journal Pharmaceutical Science 20(4): 295-299.

[18] Peterson, D. L. (2002). Looking for Risk Factors for the Acquisition of Antibiotic Resistance: A 21st Century Approach. CID 34:1564 - 1567 .

[19] Higaki S, Masaaki M, Takayoshi Y and Yoshinori H (1999). Comparative study of Staphylococci from the skin of atomic dermatitis patients and from healthy subjects. Int. J. Dermatol., 38: 265-269.

[20] Shittu, S., Kehinde, A. O., Ademola, S. A., Okesola, A. O., Oluwatosin, O. M. and Bakare, R. A. (2004). Pattern of Bacterial Pathogens in Burn Wound Infections in Ibadan Nigeria. Annal Burns Fire Disasters 17(1): 12-15.

[21] Carlo, G., Nobilio, L., Milandri, M. and Moro, M. L. (2006). Macrolide Prescriptions and Erythromycin Resistance of Streptococcus pyogenes. Clinical Infectious Diseases 42:1153-1156.

[22] Turutoglu, T., Ercelik, S. and Ozturk, E. (2006). Antibiotic Resistance of Staphylococcus aureus and Coagulase-Negative Staphylococci Isolated from Bovine Mastitis. Bulletin of Veterinary Institute Pulawy 50: 41-45. 